\title{
Pengaruh Jumlah Penduduk Miskin, Laju Pertumbuhan Ekonomi, dan Tingkat Pendidikan terhadap Jumlah Stunting di 10 Wilayah Tertinggi Indonesia Tahun 2010-2019
}

\author{
Yati Karyati* \\ Bandung, Indonesia. \\ *yatikaryati358@gmail.com
}

Prodi Ilmu Ekonomi, Fakultas Ekonomi dan Bisnis, Universitas Islam

\begin{abstract}
Stunting is a chronic nutritional problem caused by malnutrition in the long term which is now a major health problem in Indonesia. This study aims to analyze how much influence the number of poor people, Economic Growth Rate, and Education Level have on the number of stunting in the 10 highest regions of Indonesia. The data used is secondary data, namely panel data for ten years from 2010-2019 and the 10 highest regions in Indonesia sourced from the Indonesian Central Statistics Agency. The analytical analysis method used is quantitative. The model used is a fixed effect model. The results showed that the number of poor people had a positive effect, while the rate of economic growth and education level had a negative effect on the number of stunting. The conclusion of the study is that the number of poor people, the rate of economic growth, and the level of education contribute to stunting in the 10 highest regions of Indonesia. The government needs to seek to increase knowledge related to balanced nutrition, child health, and nutritional problems for children under five to parents to prevent stunting with regular promotion and counseling through village midwives.
\end{abstract}

Keywords: Stunting, Poverty, Economic Growth Rate, Education.

\begin{abstract}
Abstrak. Stunting adalah masalah gizi kronis yang disebabkan oleh kekurangan gizi dalam jangka waktu yang lama yang sekarang menjadi masalah kesehatan utama Indonesia. Penelitian ini bertujuan untuk menganalisis seberapa besar pengaruh jumlah penduduk miskin, Laju Pertumbuhan Ekonomi, dan Tingkat Pendidikan terhadap jumlah stunting di 10 wilayah tertinggi Indonesia. Data yang digunakan adalah data sekunder yaitu data panel selama sepuluh tahun dari 2010-2019 dan sebanyak 10 wilayah tertinggi di Indonesia yang bersumber dari Badan Pusat Statistika Indonesia. Metode analisis analisis yang digunakan adalah kuantitatif. Model yang digunakan adalah model fixed effect. Hasil penelitian menunjukkan bahwa jumlah penduduk miskin memiliki pengaruh positif, sedangkan Laju Pertumbuhan Ekonomi dan tingkat pendidikan memiliki pengaruh negatif terhadap jumlah stunting. Kesimpulan penelitian adalah jumlah penduduk miskin, Laju Pertumbuhan Ekonomi, dan tingkat pendidikan berkontribusi terhadap terjadinya stunting di 10 wilayah tertinggi Indonesia. Pemerintah perlu mengupayakan peningkatan pengetahuan terkait gizi seimbang, kesehatan anak, dan masalah gizi balita terhadap orang tua untuk mencegah stunting dengan promosi dan konseling secara rutin melalui bidan desa
\end{abstract}

Kata Kunci: Stunting, Kemiskinan, Laju Pertumbuhan Ekonomi, Pendidikan. 


\section{A. Pendahuluan}

Stunting merupakan salah satu target Sustainable Development Goals (SDGs) yang termasuk pada tujuan pembangunan berkelanjutan ke-2 yaitu menghilangkan kelaparan dan segala bentuk malnutrisi pada tahun 2030 serta mencapai ketahanan pangan. Target yang ditetapkan adalah menurunkan angka stunting hingga 40\% pada tahun 2025 (Pusat Data dan Informasi Kemenkes RI, 2018).

Masalah tingginya anak balita (Stunting) menjadi permasalahan yang dihadapi dunia, salah satunya negara Indonesia yang berdampak serius terhadap kualitas Sumber Daya Manusia (SDM). Stunting ini merupakan permasalahan gizi kronis yang disebabkan oleh kurangnya asupan gizi dalam rentang yang cukup lama, umumnya hal ini karena asupan makan yang tidak sesuai dengan kebutuhan gizi, sehingga mengakibatkan gangguan pertumbuhan pada anak yakni tinggi badan anak lebih rendah atau pendek (kerdil) dari standar usianya. Dengan demikian stunting ini dapat menyebabkan meningkatnya risiko terjadinya kesakitan dan kematian, perkembangan otak suboptimal dan terhambatnya pertumbuhan mental (Farah Okky et. all, 2015).

Gambar 1. Rata-rata Proporsi Stunting Balita di Asia Tenggara Tahun 2005-2019 (\%)

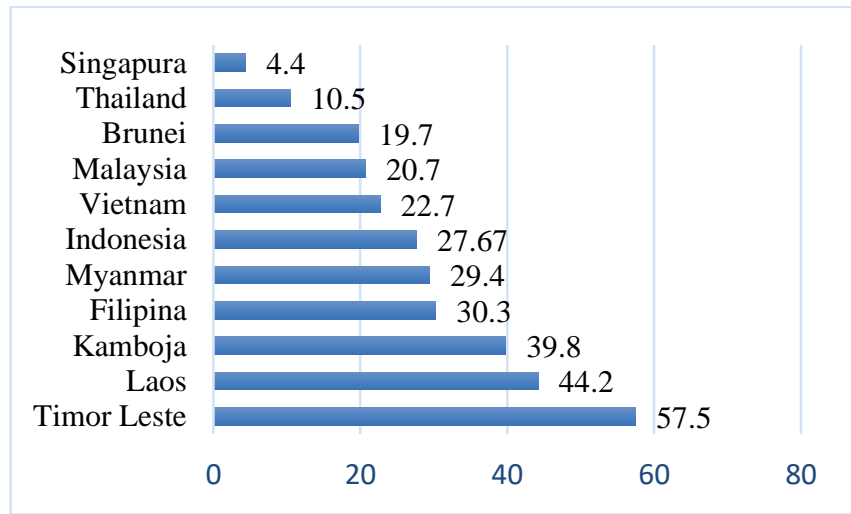

Sumber : WHO data Visualization dashboard-Child Stunting (diolah)

Berdasarkan gambar 1, Indonesia termasuk ke dalam urutan ke-6 setelah Myanmar, Filipina, Kamboja, Laos, dan Timor Leste. Rata-rata proporsi stunting Indonesia tahun 2005-2019 adalah 27,67\%. Sementara target WHO (World Health Organization) tidak lebih dari $20 \%$. Artinya secara nasional masalah stunting di Indonesia tergolong kronis atau masih tinggi dan belum menunjukkan perbaikan signifikan. Jumlah yang telah melampaui nilai standar maksimal dari Organisasi Kesehatan Dunia (WHO) yakni sebesar 20 persen atau seperlima dari jumlah total anak balita dalam suatu negara. Dengan demikian Indonesia termasuk jauh lebih tinggi dibandingkan dengan prevalensi balita stunting di negara tetangga, khususnya Singapura. Apabila dilakukan perbandingan, tingkat prevalensi balita stunting di Indonesia 7 kali lebih tinggi dibandingkan dengan tingkat balita stunting di negara Singapura tersebut. Kasus stunting di Indonesia yang masih tinggi ini mempunyai dua penyebab. Pertama, pola asuh orang tua yang salah mengenai asupan gizi. Kedua, kondisi perekonomian orang tua yang masuk dalam kategori miskin.

Tabel 1. Rata-rata Jumlah Balita Sangat Pendek dan Pendek (Stunting) Selama 10 Tahun Terakhir

\begin{tabular}{|c|c|}
\hline Provinsi & Rata-rata \\
\hline NUSA TENGGARA TIMUR & 49.88 \\
\hline NUSA TENGGARA BARAT & 41.77 \\
\hline
\end{tabular}




\begin{tabular}{|l|l|} 
SULAWESI BARAT & 41.58 \\
\hline PAPUA BARAT & 41.14 \\
\hline GORONTALO & 37.41 \\
\hline SULAWESI SELATAN & 37.07 \\
\hline KALIMANTAN TENGAH & 37.08 \\
\hline KALIMANTAN BARAT & 36.47 \\
\hline SUMATERA UTARA & 35.67 \\
\hline SULAWESI UTARA & 35.31 \\
\hline
\end{tabular}

Sumber: Badan Pusat Statistika (BPS), diolah

Tabel 1. menunjukkan bahwa Nusa Tenggara Timur merupakan provinsi dengan angka stunting yang paling tinggi. Hal ini disebabkan karena sebagian besar penduduk Nusa Tenggara Timur khususnya di Kabupaten Timor Tengah Utara masih banyaknya jumlah penduduk dengan berstatus miskin (kurang mampu) dan rendahnya tingkat pendidikan tetapi Laju Pertumbuhan Ekonomi tergolong tinggi. Pertumbuhan ekonomi Nusa Tenggara Timur apabila dilihat dari sektor yang paling unggul yaitu sektor pertanian memiliki kontribusi sebesar 28,64\%. Seharusnya dengan besarnya kontribusi pertanian tersebut dapat menekan kasus stunting karena tersedianya sumber pangan, tetapi masalahnya lahan pertanian sebagai sumber pangan tersebut dikuasai oleh borjuis lokal dari tuan tanah. Para tuan tanah ini datang dari kelompok bangsawan yang memainkan para tunggal sebagai pemilik lahan, dimana mereka menguasai banyak lahan. Situasi ini diperburuk ketika pejabat pemerintah turut andil bersikap mendukung praktik semacam ini demi menyelamatkan kepentingan mereka masing-masing. Hal ini harus mendapat perhatian serius karena keadaan ekonomi ini relatif mudah diukur dan berpengaruh besar pada konsumsi pangan.

Stunting tidak hanya dipengaruhi oleh faktor-faktor yang terkait langsung dengan kesehatan tetapi juga dipengaruhi oleh masalah sosial ekonomi seperti jumlah penduduk miskin, Laju Pertumbuhan Ekonomi, dan tingkat pendidikan. Kemiskinan dinilai mempunyai peran penting yang bersifat timbal balik sebagai sumber permasalahan gizi yakni kemiskinan menyebabkan kekurangan gizi sebaliknya individu yang kurang gizi akan memperlambat pertumbuhan ekonomi dan mendorong proses kemiskinan. Hal ini disebabkan apabila seseorang mengalami kurang gizi maka secara langsung akan menyebabkan hilangnya produktifitas kerja karena kekurangan fisik, menurunnya fungsi kognitif yang akan mempengaruhi tingkat pendidikan dan laju pertumbuhan ekonomi.

Berdasarkan hal tersebut menarik untuk dilakukan penelitian bagaimana dan seberapa besar pengaruh jumlah penduduk miskin, Laju Pertumbuhan Ekonomi, dan tingkat pendidikan terhadap jumlah stunting di 10 wilayah tertinggi Indonesia Tahun 2010-2109.

\section{B. Metodologi Penelitian}

Penelitian ini menggunakan penelitian kuantitatif dengan pendekatan deskriptif. Pendekatan kuantitatif adalah pendekatan yang digunakan dalam penelitian dengan cara mengukur indikator-indikator variabel penelitian sehingga diperoleh gambaran diantara variabel-variabel tersebut. Tujuan dari pendekatan kuantitatif menurut Sugeng (2016) adalah: "untuk mencari hubungan antarvariabel". Maka dengan demikian penulis menggunakan metode ini untuk mengetahui bagaimana hubungan antara variabel independen dengan variabel dependen.

Dalam penelitian ini data yang digunakan adalah data sekunder. Data sekunder adalah data yang digunakan untuk mendukung data primer yaitu melalui studi 
kepustakaan, dokumentasi, buku, majalah, koran, arsip tertulis yang berhubungan dengan obyek yang akan diteliti pada penelitian ini. Sumber sekunder merupakan sumber yang tidak langsung memberikan data kepada pengumpul data, misalnya lewat orang lain atau dokumen (Sugiyono, 2015: 187). Adapun data yang dilakukan dalam penelitian ini adalah:

- Data rata-rata proporsi stunting balita di Asia Tenggara tahun 2005-2019 (\%) yang diambil dari publikasi WHO data Visualization dashboard-Child Stunting (diolah)

- Data jumlah balita sangat pendek (stunting) di 10 wilayah tertinggi Indonesia tahun 2010-2019 yang diambil dari publikasi Badan Pusat Statistika.

- Data jumlah penduduk miskin di Indonesia tahun 2010-2019 yang diambil dari publikasi Badan Pusat Statistika

- Data laju pertumbuhan ekonomi tahun 2010-2019 yang diambil dari publikasi Badan Pusat Statistika

- Data Angka Partisipasi Sekolah tahun 2010-2019 yang diambil dari publikasi Badan Pusat Statistika.

Dalam penelitian ini, metode analisis yang digunakan yaitu regresi data panel. Metode ini memberikan lebih banyak kelebihan, antara lain data panel menyediakan data yang lebih banyak karena merupakan penggabungan dari dua jenis data time series dan cross section. Analisis ini menjelaskan hubungan antara variabel dependen yaitu jumlah stunting di Indonesia dan variabel independen yang berupa jumlah penduduk miskin, laju pertumbuhan ekonomi, dan tingkat pendidikan

Dalam model analisis pada penelitian ini digunakan pendekatan ekonometrika yaitu menggunakan regresi linear berganda. Analisis regresi data panel pada penelitian ini gunanya untuk mengamati hubungan antara satu variabel terikat (dependen Variable) dengan variabel bebas (independent Variabel). Uji yang dilakukan dalam penelitian ini adalah uji statistik dan ekonometrik dimana dalam uji statistik terdapat ( Koefisien Determinasi, Uji T dan Uji F). lalu dalam uji ekonometrik terdapat uji asumsi klasik yaitu Uji Normalitas, Uji Multikolinearitas, Uji Heteroskedastisitas, dan Uji Autokorelasi.

\section{Hasil Penelitian dan Pembahasan}

Data diolah dengan menggunakan metode analisis regresi data panel yang meliputi periode waktu 2015-2019 dengan jumlah observasi data 10 Provinsi di 10 wilayah tertinggi Indonesia dan diolah dengan menggunakan aplikasi e-views 10. Hasil pemilihan model terbaik menggunakan fixed effect model. Adapun hasil pemilihan model sebagai berikut :

- Uji Chow, Dengan menggunakan uji chow, diperoleh hasil probabilitas sebesar 0.0000 lebih kecil dari nilai signifikan $5 \%(0.0000 \leq \alpha 0.05)$ artinya Ho ditolak yang berarti model fixed effect lebih baik digunakan daripada model common effect.

- Uji Hausman, Dengan menggunakan uji hausman, diperoleh hasil probabilitas 0.0000 lebih kecil dari nilai signifikan $5 \%(0.000 \leq \alpha 0.05)$ artinya Ho ditolak yang berarti model fixed effect lebih baik digunakan daripada model random effect.

\section{Uji Asumsi Klasik}

Normalitas, Hasil dari penelitian ini telah memenuhi uji asumsi klasik, dimana berdasarkan pengujian normalitas diperoleh nilai probabilitas Jarque-Bera yang lebih besar dari tingkat signifikan $0.05(0.906436>0.05)$ yang artinya data berdistribusi normal.

Multikolinearitas, Menurut Gujarati \& Porter (2008) apabila nilai dari koefisien korelasi memiliki nilai diatas 0.8 antara dua variabel independent, maka dapat terindikasi gejala multikolinearitas. 
Tabel 2. Uji Multikolinearitas

\begin{tabular}{|c|c|l|l|}
\hline & $\mathrm{X} 1$ & $\mathrm{X} 2$ & $\mathrm{X} 3$ \\
\hline LN_X1 & 1.000000 & 0.157319 & -0.015816 \\
\hline $\mathrm{X} 2$ & 0.157319 & 1.000000 & 0.059633 \\
\hline $\mathrm{X} 3$ & -0.015816 & 0.059633 & 1.000000 \\
\hline
\end{tabular}

Sumber : Pengolahan data dengan Eviews 10

Berdasarkan hasil diatas, tidak terdapat korelasi antar variabel yang melebihi 0.80 artinya model regresi tersebut terbebas dari masalah multikolinearitas.

Heteroskedastisitas, Menurut Ghozali (2011), pengujian heteroskedastisitas memiliki kriteria yaitu jika tingkat signifikan diatas 5\% (0.05) berarti tidak terdapat gejala heteroskedastisitas tetapi jika dibawah tingkat signifikan 5\% (0.05) maka terjadi gejala heteroskedastisitas.

Tabel 3. Uji Heteroskedastisitas

\begin{tabular}{|c|c|c|c|c|}
\hline Variabel & Coefficient & Std. Error & $\begin{array}{c}\text { t- } \\
\text { Statistic }\end{array}$ & Prob \\
\hline C & 2.154408 & 9.925821 & 0.217051 & 0.8286 \\
\hline LN_X1 & -0.210010 & 0.384794 & -0.545774 & 0.5865 \\
\hline X2 & 0.132065 & 0.131688 & 1.002886 & 0.3184 \\
\hline X3 & 0.018368 & 0.100256 & 0.183211 & 0.8550 \\
\hline
\end{tabular}

Sumber : Pengolahan data dengan Eviews 10

Berdasarkan hasil pengujian diatas, tingkat signifikan variabel bebas yaitu Jumlah Penduduk Miskin, Laju Pertumbuhan Ekonomi, dan Tingkat Pendidikan berada di atas 0.05 yang artinya tidak terjadi masalah multikolinearitas pada persamaan regresi.

Uji Autokorelasi, Menurut Santoso (2012), kriteria ada atau tidaknya korelasi adalah jika nilai DW terletak diantara -2 samapi +2 berarti maka tidak ada autokorelasi. Berdasarkan hasil penelitian nilai DW sebesar 1.088622 yang artinya nilai tersebut lebih dari -2 sehingga tidak terjadi masalah autokorelasi pada persamaan regresi.

\section{Uji Statistik}

Koefisien Determinasi $\left(\mathrm{R}^{2}\right)$, Berdasarkan hasil dari penelitian $\mathrm{R}^{2}$ sebesar 0,620869. Nilai tersebut berarti sebesar $62.08 \%$ variasi pada Jumlah Penduduk Miskin, Laju Pertumbuhan Ekonomi, dan Tingkat Pendidikan dapat dijelaskan oleh Jumlah Stunting, sementara sisanya sebesar $37.92 \%$ ditentukan oleh variabel lain yang tidak masuk ke dalam model persamaan.

Uji t, Berdasarkan hasil uji $\mathrm{t}$ atau uji parsial, Jumlah Penduduk Miskin berpengaruh positif signifikan terhadap jumlah stunting di 10 wilayah tertinggi Indonesia dengan nilai probabilitas 0.0017 (< 0.05). Laju Pertumbuhan Ekonomi berpengaruh negatif signifikan terhadap jumlah stunting di 10 wilayah tertinggi Indonesia dengan nilai probabilitas sebesar $0.0042(<0.05)$. Dan tingkat pendidikan berpengaruh negatif signifikan terhadap jumlah stunting di 10 wilayah tertinggi Indonesia dengan nilai probabilitas sebesar $0.0005(<0.05)$. 
Uji f, Hasil pengujian didapat nilai probabilitas f-statistik untuk variabel bebas sebesar (0.000000) lebih kecil dibandingkan dengan nilai probabilitas (0.05). Artinya secara bersama-sama variabel bebas yaitu jumlah penduduk miskin, Laju Pertumbuhan Ekonomi, dan tingkat pendidikan berpengaruh secara simultan terhadap jumlah stunting di 10 wilayah tertinggi Indonesia.

\section{Hasil Estimasi Model}

Adapun hasil estimasi dengan menggunakan aplikasi eviews 10 adalah sebagai berikut:

Tabel 4. Hasil Estimasi Model

\begin{tabular}{|c|c|c|c|}
\hline Variabel & Coefficient & t-Statistic & Prob. \\
\hline C & 400.9382 & 5.990190 & 0.0000 \\
\hline LN_X1 & 31.88357 & 4.231192 & 0.0017 \\
\hline X2 & -0.356753 & -1.413205 & 0.0042 \\
\hline X3 & -1.772971 & -9.154559 & 0.0005 \\
\hline
\end{tabular}

Sumber: Pengolahan data dengan Eviews 10

Sehingga dapat ditulis persamaan matematisnya sebagai berikut:

Yit $=\beta \mathrm{o}+\beta 1 \mathrm{LN}(\mathrm{X} 1)$ it $+\beta 2(\mathrm{X} 2)$ it $+\beta 3(\mathrm{X} 3)$ it $+\mathrm{e}$

Dimana:

Yit $\quad=$ Jumlah Stunting

Bo $\quad=$ Konstanta

$\beta 1 \ldots \beta 3=$ Koefisien regresi masing-masing variabel

LN $(\mathrm{X} 1)=$ Jumlah Penduduk Miskin

$\mathrm{X} 2=$ Laju Pertumbuhan Ekonomi

X3 = Tingkat Pendidikan

e $\quad$ eror term

Hal tersebut menunjukkan:

1. Jika variabel independent (jumlah penduduk miskin, Laju Pertumbuhan Ekonomi, dan tingkat pendidikan) bernilai 0 , maka variabel jumlah stunting akan mengalami peningkatan sebesar 400.9382 .

2. Pada variabel Jumlah Penduduk Miskin (LN_X1), menunjukkan koefisien positif. Jadi jika terjadi peningkatan sebesar satu persen maka akan meningkatkan jumlah stunting sebesar 31.88357.

3. Pada variabel Laju Pertumbuhan Ekonomi (X2), menunjukkan koefisien negatif. Jadi jika terjadi peningkatan sebesar satu persen maka akan menurunkan jumlah stunting sebesar 0.356753 .

Pada variabel Tingkat Pendidikan (X3), menunjukkan koefisien negatif. Jika terjadi peningkatan sebesar satu persen maka akan menurunkan jumlah stunting sebesar 1.772971.

\section{Pengaruh Jumlah Penduduk Miskin Terhadap Jumlah Stunting}

Jumlah Penduduk Miskin memiliki hubungan positif dan berpengaruh signifikan terhadap jumlah stunting, nilai probabilitas sebesar 0.0017 dan nilai koefisien sebesar 31.88357. Nilai tersebut berarti jika terjadi peningkatan sebesar $1 \%$ maka jumlah stunting di 10 wilayah tertinggi Indonesia akan meningkat sebesar 31.88357. Dengan demikian hasil ini sesuai dengan hipotesis penelitian.

Kemiskinan menjadi salah satu penyebab stunting yang dominan. Keterbatasan ekonomi membuat masyarakat tidak sanggup memenuhi kebutuhan gizi yang seimbang. Kerja keras untuk memperoleh penghasilan yang layak pun berujung pada pola asuh yang salah yang bisa berkontribusi pada stunting (Indriyani, 2018). 
Hasil penelitian ini juga sesuai dengan penelitian Raisuli Ramadhan (2018) dan Haerawati Idris (2020), banyaknya penduduk yang berstatus miskin akan mempengaruhi status gizi balita karena disebabkan oleh kurangnya masukan makanan yang bergizi sehingga dapat menyebabkan bertambahnya stunting di Indonesia.

\section{Pengaruh Laju Pertumbuhan Ekonomi Terhadap Jumlah Stunting}

Laju Pertumbuhan Ekonomi memiliki hubungan negatif dan berpengaruh signifikan terhadap jumlah stunting, nilai probabilitas sebesar 0.0042 dan nilai koefisien sebesar 0.356753. Nilai tersebut berarti jika terjadi peningkatan sebesar $1 \%$ maka jumlah stunting di 10 wilayah tertinggi Indonesia akan menurun sebesar 0.356753 . Dengan demikian hasil ini sesuai dengan hipotesis penelitian.

Suatu perekonomian dikatakan mengalami pertumbuhan apabila tingkat kegiatan ekonomi lebih tinggi daripada apa yang telah dicapai sebelumnya. Artinya, pertumbuhan baru tercipta apabila jumlah barang dan jasa yang dihasilkan dalam perekonomian tersebut menjadi bertambah besar pada tahun-tahun berikutnya. Laju Pertumbuhan Ekonomi di 10 wilayah tertinggi Indonesia selama kurun waktu 20102019 mengalami peningkatan secara terus menerus (Ahmad Soleh, 2020).

Hasil penelitian ini juga sesuai dengan penelitian Harniwita (2008) dan Dian Wahyuni (2020), dengan meningkatnya Laju Pertumbuhan Ekonomi akan mendorong kesempatan kerja yang semakin luas sehingga dapat meningkatkan pendapatan masyarakat yang akhirnya akan menyebabkan stunting menjadi turun.

\section{Pengaruh Tingkat Pendidikan Terhadap Jumlah Stunting}

Tingkat pendidikan memiliki hubungan negatif dan berpengaruh signifikan terhadap jumlah stunting, nilai probabilitas sebesar 0.0005 dan nilai koefisien sebesar -1.772971 . Nilai tersebut berarti jika terjadi peningkatan sebesar $1 \%$ maka jumlah stunting di 10 wilayah tertinggi Indonesia akan menurun sebesar 1.772971. Dengan demikian hasil ini sesuai dengan hipotesis penelitian.

Hasil penelitian ini juga sesuai dengan penelitian Cholifatun (2015) dan Anggunan (2020), semakin tinggi tingkat pendidikan seseorang maka akan semakin banyak pengetahuan yang didapatnya contohnya seperti pola asuh terhadap anaknya, maka dengan hal ini akan mengurangi jumlah stunting.

\section{Kesimpulan}

Berdasarkan pembahasan dalam penelitian ini, peneliti menyimpulkan beberapa hasil penelitian sebagai berikut:

1. Hasil perhitungan koefisien determinasi (R2) sebesar 0,620869 mengindikasikan bahwa variabel jumlah penduduk miskin, Laju Pertumbuhan Ekonomi, dan tingkat pendidikan memiliki pengaruh sebesar $62.08 \%$ yang dapat dijelaskan dalam persamaan model, untuk sisanya sebesar $37.92 \%$ dipengaruhi oleh variabel lain di luar model. Sedangkan berdasarkan hasil uji-F statistik sebesar 14.51029 dengan probabilitas $\mathrm{F}$ sebesar 0.000000 lebih kecil dibandingkan dengan taraf signifikan 0.05. Hal ini menjelaskan bahwa secara bersama-sama variabel bebas yaitu jumlah penduduk miskin, Laju Pertumbuhan Ekonomi, dan tingkat pendidikan berpengaruh signifikan terhadap jumlah stunting di 10 wilayah tertinggi Indonesia.

2. Berdasarkan hasil regresi pada variabel jumlah penduduk miskin menghasilkan koefisien positif, maka dengan demikian jika terjadi peningkatan sebesar satu persen akan meningkatkan jumlah stunting sebesar 31.88357. Hal ini berbeda dengan hasil regresi variabel Laju Pertumbuhan Ekonomi dan tingkat pendidikan, dimana LPE dan tingkat pendidikan menghasilkan koefisien negatif. Jika terjadi peningkatan sebesar satu persen pada LPE maka akan menurunkan jumlah stunting sebesar 0.356753. Sedangkan jika 
terjadi peningkatan sebesar satu persen pada tingkat pendidikan maka akan menurunkan jumlah stunting sebesar 1.772971 .

\section{Acknowledge}

Peneliti mengucapkan kepada pihak Universitas Islam Bandung dan Badan Pusat Statistik Indonesia yang telah mendukung dan membantu dalam memberikan informasi maupun data dalam menyelesaikan tulisan ini. Serta tak lupa juga terima kasih kepada Aan Julia, S.E.,M.Si dan Westy Riani, S.E.M.SE.Sy yang telah membimbing dan memberikan arahan agar terselesaikannya tulisan ini.

\section{Daftar Pustaka}

[1] Anggunan. 2020. Hubungan Tingkat Pendidikan Ibu dan Pendapatan Keluarga dengan Kejadian Stunting pada Anak Usia 6-59 Bulan. Jurnal Kebidanan. Vol. 6 No.2. Hal 205-211.

[2] Badan Pusat Statistik-BPS. 2010-2019. Angka Partisipasi Sekolah. (online). DKI Jakarta. Indonesia

[3] Badan Pusat Statistik-BPS. 2009-2019. Kemiskinan dan Ketimpangan (online). DKI Jakarta. Indonesia.

[4] Badan Pusat Statistik-BPS. 2010-2019. Laju Pertumbuhan PDRB atas Harga Konstan (online). DKI Jakarta. Indonesia.

[5] Badan Pusat Statistik-BPS. 2009-2019. Prevalensi Jumlah Bayi Sangat Pendek dan Pendek Stunting di Indonesia (online). DKI Jakarta. Indonesia.

[6] Cholifatun \& Lailatul. 2015. Hubungan Tingkat Pendidikan, Tingkat Pengetahuan dan Pola Asuh Ibu dengan Wasting dan Stunting pada Balita Keluarga Miskin. Jurnal Media Gizi Indoneisa. Vol. 10 No. 1. Hal 84-90.

[7] Ghozali, Imam. 2005. Aplikasi Analisis Multivariate dengan Program SPSS. Semarang: Badan Penerbit Universitas Diponegoro.

[8] Gujarati, D. N \& Porter, D. C. 2009. Basis Econometrics. 5th ed. New York : McGraw-Hill Irwin.

[9] Haerawati, Idris. 2020. Faktor Sosial Ekonomi dan Pemanfaatan Posyandu dengan Kejadian Stunting Balita Keluarga Miskin Penerima PKH di Palembang. Jurnal Gizi Klinik Indonesia. Vol. 17 No. 1. Hal 22-33.

[10] Harniwita. 2008. Pengaruh Tingkat Pendapatan Terhadap Gizi Keluarga di Desa Buluh Cina Kecamatan Siak Hulu Kabupaten Kampar. Jurnal Penelitian. Vol. IX No. 1. Hal 112-116.

[11] Indriyani et. all. 2018. Stunting, Faktor Resiko dan Pencegahan. Jurnal Agromedicine. Vol. 5 No. 1 . Hal 540-545.

[12] Nurwati. 2008. Kemiskinan: Model Pengukuran, Permasalahan dan Alternatif Kebijakan. Jurnal Kependudukan Padjajaran. Vol. 10 No. 1. Hal 1-11.

[13] Okky, et. all. 2015. Faktor-faktor yang Mempengaruhi Kejadian Stunting Pada Anak Balita di Wilayah Pedesaan dan Perkotaan. Jurnal Penelitian Kesehatan. Vol. 2 No. 4. Hal 236-245.

[14] Ramadhan, Raisuli. 2018. Determinasi Penyebab Stunting di Provinsi Aceh. Jurnal Penelitian Kesehatan. Vol. 5 No. 2. Hal 71-79.

[15] Sukirno. 2011. Makroekonomi: Teori Pengantar. Jakarta: PT Raja Grafindo Pustaka.

[16] Soleh, Ahmad. 2012. Analisis Pertumbuhan Ekonomi dan Kesenjangan Pembangunan Ekonomi Antara Region Di Indonesia Tahun 2001-2010. Jurnal Analisa Sosiologi. Vol. 3 No. 1. Hal 70-90.

[17] Wahyuni, Dian. 2020. Pengaruh Sosial Ekonomi dengan Kejadian Stunting Pada Balita di Desa Kuala Tambang Kampar. Jurnal Kesehatan Masyarakat. Vol. 4 No. 1. Hal 20-26. 